\title{
REFUSAL AND ACCEPTANCE STRATEGIES REALIZATION IN SUNDANESE CONTEXT
}

\author{
Sartin T. Miolo \\ Language Education, Post Graduate of Universitas Negeri Jakarta, Indonesia \\ E-mail: sartinmiolo@yahoo.co.id; sartin@ung.ac.id \\ Emzir \\ Language Education, Post Graduate of Universitas Negeri Jakarta, Indonesia \\ E-mail: emzir.pb@gmail.com
}

\section{Asep Supriadi}

Department of English Education, Universitas Kuningan, Indonesia

E-mail: asep.supriadi13@yahoo.com

\begin{abstract}
APA Citation: Miolo, S. T., Emzir, \& Supriadi, A. (2018). Refusal and acceptance strategies realization in Sundanese context. Indonesian EFL Journal, 4(2), 71-79. doi: 10.25134/ieflj.v4i2.1378.
\end{abstract}

\begin{abstract}
This study investigates the refusal and acceptance strategies realization in sundanese context among students of a private university in Kuningan. The study is purposely designed to investigate the types of refusal and acceptance strategies used in Sundanese context. This study employed a qualitative method as a research design. A Discourse Completion Task (DCT) was used to collect the data which was spread into 30 respondents. The questionnaire was in Bahasa Sunda because the respondents were Sundanese people, so it can be easier to be analyzed. The findings showed that there were 240 utterances consisted of 150 utterances of refusal and 90 utterances of acceptance. The refusal strategies consisted of 12 strategies and the acceptance strategies consisted of 6 strategies. Most of the respondents which are Sundanese are polite as it can be seen from their responses when they were asked to accompany their lecturer or when they refused to the person with higher power. They always say punten, hapunten sateuacana or it can be called 'sorry'. The term 'sorry' showed that they try to be polite when talking with the higher power and distance. Yet, they use different talking when they talk to their friends who have the same power. So, they can place where they should be polite and to whom they talk.
\end{abstract}

Keyword: acceptance strategy, refusal strategy, sundanese culture.

\section{INTRODUCTION}

In a real life, someone will feel satisfy when they are meeting people and can communicate with them through speaking. The communication can be various depends on the aim or the context of their speaking. It can be request, statement, command or other through direct or indirect. We may have to use indirectness because of some performance error. The use of indirectness in these circumstances may lead the hearer to infer all sorts of thing about you, but you can not be said to have generated any impicature (Thomas, 1995, p. 120).

When we request someone to take something, there will be "pangmeulikeun" or "pangmeserkeun". As the Sundanese people, learning Sundanese language is more difficult that learning English or using Indonesia language. There are many rules in Sundanese that should be obeyed if we want to speak Sundanese. It is a proof that there are cultural differences between sundanese and other. According to Oatey $(2010$, p. 50), culture can 
be characterized as a system of cultural representations. A cultural representation is a particular type of metarepresentation (i.e. representation of a representation).

This study is focused on refusal and acceptance realization in Sundanese culture at a University in Kuningan. This research investigates the refusal and acceptance strategies in Sundanese context in Kuningan. Indirectness is best regarded as part of the speaker's wisdom. When we will refuse somebody request, we can not be direct to refuse it because the Sundanese will more focus on the politeness. They will refuse indirectly to save their face and also the speaker's face.

Requesting is an utterance frequently used by speakers in daily conversation. In using requesting, the speaker attempts to make hearer do what speaker wants but the hearer feels free to choose wheather refuse or accept it. Thirdly is because requesting are used to get greatest attention from listener in communication. Through requesting the speaker utterances make hearer do something and can refuse or accept what people ask for.

There are 746 languages in Indonesia such as Sundanese, Balinese, Javanese, etc. Sundanese becomes the main topic because we know that mostly Indonesian people used Sundanese as their habitual language. Besides, the background of the researcher is also Sundanese. To do this, the sundanese culture especially in language should be studied to give deeply understanding to the people.

To make clear about refusal and acceptance strategies realization in sundanese context, this study involved 30 respondents of students at a university in Kuningan to get the answer of two research questions: (1) what are the types of refusal strategies used in Sundanese context? and (2) what are the types of acceptance strategies used in Sundanese context?

All languages have different way of refusing and use various strategies while refusing in order to make themselves and others comfortable. A refusal can be expressed either explicitly or implicitly. In Indonesia, an explicit refusal is always marked by negator tidak "no" or its (non-standard) variants such as nggak, ndak, ogah, etc (Aziz, 2000, p. 81). An acceptance is a response provided by respondents will be categorized as an acceptance if the headact of the sequence of the response or the illocutionary point indicates the speaker's willingness to fulfill the request addressed to him/her (Aziz, 2000, p. 77).

The refusal strategies consist of 12 strategies such as hesitation and lack of enthusiasm, this strategy is said when the person wants to refuse something by manipulating their refusing. Offer an alternative means that when the speaker regards the interlocutor's request as being in need of immediate fulfillment but on the other hand he/she is already committed to complying with his/her schedule, the speaker is inclined to offer an alternative to his/her interlocutor (Aziz, 2000). Postponement means that the speakers do not immediately accept or refuse the interlocutors' requests, but they deliberately delay their answer (Aziz, 2000 , p. 84). Put the blame on a third party explain, in order to protect themselves from either immediate or subsequent consequences, speakers scapegoat a third party or state of affairs which prevents them from fulfilling the interlocutors' requests (Aziz, 2000, p. 85).

General acceptance of an offer but giving no details tell about indefiniteness implies the speaker's unwillingness to act on the request and the speaker's hesitation to directly refuse the request (Aziz, 2000, p. 85-86). General acceptance with excuse explain that the speaker seems to have accepted the interlocutor's request, but she/he eventually negated it in the concluding sequence for some reason (Aziz, 2000, p. 86). Giving reason and explanation tell about although this strategy clearly indicates a refusal, it is quite different from the direct refusal using the negotator tidak, in some cases the speakers appear to be vague in his/her refusal (Aziz, 2000, p. 87). Complaining and criticizing tell about the manner in which the expressions are uttere, this indirect refusal will be perceived by the interlocutor as a blunt refusal. 
Conditional yes give an explanation that the speaker is willing to carry out the request expressed by his/her interlocutor if certain conditions are fulfilled. Questioning the justification of a request, as an indirect refusal which employs rhetorical questions, this strategy is mainly aimed at convincing the interlocutor that his/her request is unacceptable (Aziz, 2000, p. 89). Threatening tell the speaker does not accept and refuse the interlocutor's request directly, but she is instead threatens the interlocutors not to request something to her. Comments without exemplification explain the responses clearly indicated that the respondents would either accept or refuse the request uttered by their interlocutor.

While, the strategy of accepting consists of 6 strategies such as general yes or IFID that a response provided by respondents will be categorized as an acceptance if of the sequence of the response or the illocutionary points indicates the speaker's willingness to fulfill the request addressed to him/her (Aziz, 2000, p. 77). A rethorical response which refers to the strategy in which the speaker gives a rhetorical answer to his/her interlocutor as arespons to the request addressed to him or her (Aziz, 2000, p. 78). Expression of solidarity means that there are occasions in which the speaker found that fulfilling his / her interlocutor's request was equally important to that of fulfilling his / her scheduled plans (Aziz, 2000, p. 79).

Acceptance with reservations tell the respondent agreed to perform an act as requested by their interlocutors if particular conditions are meet (Aziz, 2000, p. 79). Noncommittal responses, this category refers to a category of responses that the speaker does not give a spesific answer. Comments without exemplification, this strategy can be acceptance and also refusals because the responses clearly indicated that the respondents would either accept or refuse the request uttered by their interlocutor (Aziz, 2000, p. 94).

\section{METHOD}

In this research, qualitative research is used as research design. Geerts (1976, p. 235) in Maxwell (1996,p. 4) described design in qualitative research is an interative process that involves "tacking" back and forth between the different components of the design, assessing the implications of purposes, theory, research question, methods and validity threats for one another.

The object of this research need 30 students of the university in Kuningan which comes from sundanese. Data source of this research were chosen by using purposive sampling. Sugiyono (2012, p. 124) defines purposive sampling is a technique of determining a sample with certain consideration. In line with Sugiyono, Maxwel (1996, p. 70) states that purposeful sampling is a strategy in which particular settings, persons or events are selected deliberately in order to provide important information that can not be gotten as well from other choices.

The participants chosen because of some consideration such as: Even they are pointed out from different background, but they should be sundanese which come from every district in Kuningan. The different background indicates the variety of using sundanese language. Besides different background, they are also pointed out from every faculty, they should have quality in speaking and writing because this requesting strategy are shown both in speaking and writing.

DCT (Discourse Completion Task) is used to collect data. DCT data can, therefore, be regarded as indirectly representing "a participant's accumulated experience within a given setting" (Golato 2003, p. 92). Responses to written questionnaires have been shown to "reflect the values of the native culture" (Beebe \& Cummings 1996, p. 75), and defined as metapragmatic on the grounds that they represent culture-specific beliefs about what constitutes appropriate behaviour (Golato 2003, p. 111) in Ogeirmann (1984, p. 69).

This type of questionnaire enabled the researcher to reach large number of respondents and make statistical control for variables and analyze the data accordingly. 
The questionnaire consisted of eight hypothesized situations. Generally, a DCT consists of descriptions of situations to which the subjects are expected to react and thereby provide the desired speech act (open DCT) (Ogeirmann,1984, p. 81). Sometimes the description is followed by an incomplete dialogue consisting of an initiating or a closing line of dialogue. DCTs with several turns requiring the respondents to provide two answers or both interlocutors' conversational turns have also been used to collectspeech act data.

There are 8 situations in this study that describe the different level of the speaker. The situations are given in Bahasa Sunda to find out sundanese's habit in using the indirectness of requesting in sundanese culture. The respondents should fill out the answer based on the questions which is aimed to equal to equal, younger to elder and elder to younger.

\section{RESULTS AND DISCUSSION}

Based on the data, from eight situations spread out to 30 respondents, there are 240 utterances that also consist of 150 utterances of refusing and 90 utterances of accepting. The refusal strategies consist of 12 strategies such as hesitation and lack of enthusiasm, offer an alternative, postponement, put the blame on a third party, general acceptance of an offer but giving no details, general acceptance with excuse, giving reason and explanation, complaining and criticizing, conditional yes, questioning the justification of a request,threatening and comments without exemplification. While, the strategy of accepting consists of 6 strategies such as general yes or IFID, a rethorical response, expression of solidarity, acceptance with reservations, non-committal responses and comments without exemplification. The detail description of refusing and accepting strategies are shown in the table below:

Table 1. The description frequency of refusal strategies

\begin{tabular}{clc}
\hline No & \multicolumn{1}{c}{ Strategies } & Frequency \\
\hline 1. & Hesitation and lack of enthusiasm & 32 \\
2. & Offer an alternative & 19 \\
3. & Postponement & 10 \\
4. & Put the blame on a third party & 4 \\
5. & general acceptance of an offer but giving no detail & 3 \\
6. & General acceptance with excuse & 26 \\
7. & Giving reason and explanation & 34 \\
8. & Complaining and criticizing & 1 \\
9. & Conditional yes & 3 \\
10. & Questioning the justification of a request & 5 \\
11. & Threatening & 4 \\
12. & Comments without exemplification & 8 \\
\hline \multicolumn{2}{c}{ Frequency } \\
\hline
\end{tabular}

Table 2. The description frequency of acceptance strategies

\begin{tabular}{clc}
\hline No & \multicolumn{1}{c}{ Strategies } & Frequency \\
\hline 1. & IFID & 10 \\
2. & Expression of solidarity & 9 \\
3. & A rhetorical response & 21 \\
4. & Acceptance with reservation & 12 \\
5. & Non-committal responses & 33 \\
6. & Comments without exemplification & 5 \\
\hline \multicolumn{2}{r}{ Frequency } & $\mathbf{9 0}$ \\
\hline
\end{tabular}

\section{Refusal strategies}

All languages have different way of refusing and use various strategies while refusing in order to make themselves and others comfortable. 


\section{Hesitation and lack of enthusiasm}

This strategy is said when the person wants to refuse something by manipulating their refusing. The person feel more impolite by doing this strategy rather than using the negator "tidak", the people choose to save their face (Aziz, 2000, p. 83). The following sample are taken from the respondents :

Hapunten sateuacana, manawi abdi kirang sae dina nyandakeun acara anu sakral ieu $(\mathrm{R} 3, \mathrm{~S} 1)$.

(sorry maybe I was not verygood in bringing an event).

Aduh punten, keenjing na abdi bade UAS upami nonton piala dunia teh bilih ke enjing nundutan. (R8,S7).

(oh sorry I will get final exam tomorrow if I watch the world cup, I fear that I will be so sleepy tomorrow).

The samples above clearly explain their responses, let the interlocutors know their answer implicitly. They give the signal like "manawi abdi kirang sae" and "ke enjingna abdi bade uas", both of it showed the signal of the speakers that the interlocuter's request are uncceptable.

\section{Offer an alternative}

When the speaker regards the interlocutor's request as being in need of immediate fulfillment but on the other hand he/she is already committed to complying with his/her schedule, the speaker is inclined to offer an alternative to his/her interlocutor (Aziz, 2000, p. 83). These are the following examples are taken from the respondents which answered the offer an alternative situation.

Haduh, hapunten anu dipikasuhun, manawi abdi teh bade aya kagiatan di kampus janten teu tiasa nurutkeun kahoyong baraya. Kumaha lamun si udin bae pan si eta mah tos sering (R28, S1).

(oh sorry, I have events in my campus so I can not follow your wishes. what if Udin because he's smart in bringing an event).

Hapunten, abdi teu wantun kangge mawakeun acara lantaran abdi tara biasa. Ke wae abdi miwarang pun raka anu tos biasa $(\mathrm{R} 21,21)$.

(sorry I can not be a host because I have not been accustomed to. Let me ask my brother because he is experienced in bringing the show)

From that three data above, the respondents showed their regret by saying 'punten kang'. They feel regret because they can not fill what the interlocutor asked for. Thus, the speaker offer an alternative to save both the speaker's face and the hearer's face. When the speaker wants to refuse the interlocutor who asked them for being a host, they might give an alternative way such as "ke wae abdi miwarang pun raka anu tos biasa" or "kumaha lamun si udin wae pan si eta mah tos sering".

\section{Postponement}

The speakers do not immediately accept or refuse the interlocutors' requests, but they deliberately delay their answer (Aziz, 2000, p. 84). These are the following examples are taken from the respondents which answered the postponement situation.

Bade aya pamengan abdi teh, kedah dongkap ka bumi mamah ongkoh (R23, S6).

(I will have an activity, then I should go to my mother's house).

Abdi teh teu acan ngerjakeun tugas teras dipiwarang ngajajap mamah (R23, S3).

(I haven't finished my task yet then my mom asked me to accompany her).

The data above tell that the speakers do not accept also do not refuse the interlocuters' requests. The data 6 showed that the speaker delay the answer by giving the answer in a long-winded. When they were asking for having dinner with their new neighbour, they said that they will have an activity then go to their mother's house.

\section{Put the blame on a third party}

This strategy has a less respons from the respondent. Only 4 utterances that using this strategy. In order to protect themselves from either immediate or subsequent consequences, speakers scapegoat a third party or state of affairs which prevents them from fulfilling the interlocutors' requests (Aziz, 2000, p. 85). These are the following examples are taken from the respondents which answered put the blame on a third party situation.

Hapunten pa, kaleresan abdi aya peryogi ka bumi sepuh. Janten teu tiasa sumping (R1, S6).

(Sorry sir, in advertent I have an event in my parent's house. So I can't come).

Punten poe eta teh abdi bade aya tamu ka rompok (R30, S1).

(Sorry, that day I will have a guest).

General acceptance of an offer but giving no detail

This strategy is simply because such indefiniteness implies the speaker's 
unwillingness to act on the request and the speaker's hesitation to directly refuse the request (Aziz, 2000, p. 85-86). This can be said that the speaker implies to accept but she/he does not accept it in a whole. These are the following examples are taken from the respondents which answered general acceptance of an offer but giving no detail situation.

Kaleresan abdi teh tos tuang di rompok, muhun atuh sakedik wae hun (R8, S5).

(I happened to have eaten at home. Let me eat a little).

Hapunten ibu abdi teu tiasa dongkap ka bumi ibu lantaran aya acara husus. Tapi insaallah ke ku abdi diusahakeun dongkap sakedap (R15, S6).

(sorry mom, I cannot come to your home because I had aspecial event. But insha Allah I'll try to come up briefly).

The data told that the speaker accept the interlocuter's request but they did not promise to make it happen fully. They did not ensure their answer wheather refuse or accept it clearly.

\section{General acceptance with excuse}

In the first sequence of his/her utterance, the speaker seems to have accepted the interlocutor's request, but she/he eventually negated it in the concluding sequence for some reason (Aziz, 2000, p. 86). It can be concluded that this strategy make the speaker like to accept but at the end she/he refuse it. These are the following examples are taken from the respondents which answered general acceptance with excuse situation.

Nampi pisan undangan tuangna, mung pun ibu kaleresan nuju ngayakeun acara kulawargi (R7, S6).

(I accept it but my mother is held the family event). Abdi saleresna hoyong dongkap ka acara ibu mung abdi ke wengi kedah ka bumi pun biang (R29, S6). (exactly, I want to come to your event but I should come to my wife's house tonight).

\section{Giving reason and explanation}

Although this strategy clearly indicates a refusal, it is quite different from the direct refusal using the negotator tidak, in some cases the speakers appear to be vague in his/her refusal (Aziz, 2000, p. 87). The speaker gives the reason and explanation why they can not accept the interlocutor's request indirectly. These are the following examples are taken from the respondents which answered giving reason and explanation situation.

Hatur nuhun sateuacana tos nawisan $\mathrm{ka}$ abdi kaleresan sim kuring parantos tuang nembe pisan dirompok (R30, S5).

(Thanks already offered me, but I have already eaten in my house).

Hapunten pisan abdi teu tiasa kumargi aya tugas kangge ke enjing (R27, S3).

(I'm really sorry, I can't because I have task for tommorrow)

\section{Complaining and criticizing}

The speakers avoided using the negator tidak or its variants, yet they used other means of expressing their off-record refusals. There is only 1 utterance which used this strategy. That utterance is in the situation 3 used by the last respondent.

Nuhun mih da atos emam tuda wareg (R30, S3).

(Thanks mom, I have eaten, still full).

Looking at the manner in which the expressions are uttered, this indirect refusal will be perceived by the interlocutor as a blunt refusal (Aziz, 2000, p. 88).

\section{Conditional yes}

The speaker is willing to carry out the request expressed by his/her interlocutor if certain conditions are fulfilled. However, from the interlocutor's point of view, such reserved condition can be regarded as being unfairly proposed (Aziz, 2000, p. 88). They can accept something with a specific reason that the exact is that the speaker can not do it. These are the following examples are taken from the respondents which answered conditional yes situation.

Padahal abdi teh gaduh padamelan nu sanes tapi teu nanaon tiasa ke wengi ngadamelanna (R21, S3).

(Exactly, I have another task but it's never mind. I can do it tonight).

Nuhun pa tapi panginten abdi mung sakedap wae dongkapna kumargi aya kaperyogian (R9, S6).

(Thanks sir, but only for a while I came because I have an event).

\section{Questioning the justification of a request}

As an indirect refusal which employs rhetorical questions, this strategy is mainly aimed at convincing the interlocutor that his/her request is unacceptable (Aziz, 2000, p. 89). The speaker does not believe the interlocutor's request. These are the following examples are taken from the respondents 
which answered questioning the justification of a request situation.

Kabener? Geuning urang sih? (R17, S1).

(Really? Why should I?).

Sugan ke peuting piala dunia? Kabener? (R21, S7).

(Is the world cup tonight? Really?).

The speaker used 'really?' or kabener? as their respond to the interlocutor's utterance.

\section{Threatening}

The speaker does not accept and refuse the interlocutor's request directly, but she is instead threatens the interlocutors not to request something to her. These are the following examples are taken from the respondents which answered threatening situation.

Duh kumaha nya! Teu tiasa heh upami dipaksakeun bilih ngarusak acara (R10, S1).

(Ouch, sorry I can't. If I am forced, I'm afraid that I will destroy the event).

The speaker threats the interlocutor that if the interlocutor forced him to do what he wants, the speaker will destroy the event.

\section{Comments without exemplification}

The responses clearly indicated that the respondents would either accept or refuse the request uttered by their interlocutor. These are the following examples are taken from the respondents which answered comments without exemplification situation.

Hapunten pa nuju aya peryogi nu sanes, kedah ngumpulkeun tugas kangge ke enjing (R4, S3).

(I'm sorry sir, I have another task, I should collect my task for tomorrow ......).

Hapunten pa, margi abdi teu tiasa ngarencangan bapa rapat kumargi abdi teh nuju seueur tugas sareng waktosna tos meped (R17, S3).

(Sorry sir, I can't accompany you meeting because I have alot of task and I have no time).

\section{Acceptance strategies}

A response provided by respondents will be categorized as an acceptance if the headact of the sequence of the response or the illocutionary point indicates the speaker's willingness to fulfill the request addressed to him/her (Aziz, 2000, p. 77).

\section{IFID}

A response provided by respondents will be categorized as an acceptance if of the sequence of the response or the illocutionary points indicates the speaker's willingness to fulfill the request addressed to him/her (Aziz, 2000, p. 77). It can be known that this strategy make the speaker accept the interlocutor's request explicitly. These are the following examples are taken from the respondents which answered IFID situation:

Mangga (R6, S2).

(Okay).

Abdi nampi pisan pa (R27, S8).

(I really accept it sir).

The term mangga and abdi nampi pisan pa explicitly tell that the speaker really accept the request directly to the interlocutors.

\section{Expression of solidarity}

There are occasions in which the speaker found that fulfilling his / her interlocutor's request was equally important to that of fulfilling his / her scheduled plans (Aziz, 2000 , p. 78-79). These are the following examples are taken from the respondents which answered expressin of solidarity situation.

Teh saleresna mah abdi teh sibuk, tapi tos teu nanaon. Insya allah, abdi teu enak ka teteh. Mung ka teteh bae abdi kersa (R9, S2).

(Actually I'm busy but it's ok. Insya Allah I will).

Abdi isin mang, tapi pami nolak abdi henteu enak ka mamang (R22, S4).

(Uncle, I'm shy. But I will not refuse because of you).

\section{A rhetorical response}

This strategy refers to the strategy in which the speaker gives a rhetorical answer to his/ her interlocutor as arespons to the request addressed to him or her. The speaker used this strategy as their respons by giving rhetorical answer means they accept the interlocutor's request implicitly. These are the following examples are taken from the respondents which answered a rhetorical answer situation.

Kaleresan abdina nuju rineh. Dikawitan dinten iraha? (R16, S2).

(I am free exactly. When it will be held?).

Bade dinten naon ngawitana? (R28, S2).

(When it will be started?). S4).

Dianggo henteu ku mamang laptopna? (R8,

(Do you use your computer?).

The speaker asked the interlocutor as their respond of acceptance. When the interlocutor 
ask them to teach his/her little brother, the speaker ask when it will be started so they implicitly accept to teach the interlocutor's little brother.

\section{Acceptance with reservation}

The respondent agreed to perform an act as requested by their interlocutors if particular conditions are meet (Aziz, 2000, p. 79). This strategy must be regarded more as an acceptance than a strategy of declination. These are the following examples are taken from the respondents which answered acceptance with reservation situation.

Nya pami teu aya nu keursaeun, abdi oge teu nanaon nu ngajar mah asalkeun budakna nurut (R20, S2).

(Well, ifyour sisteris willingIalsodo not mindas long ashe keepsme).

Mangga tapi hapunten pisan pami abdi nuhunkeun artos bayarana dipayun kumargi abdi butuh pisan (R13, S2).

(Of course, but what iflasked forpayment at the beginningbecauseI really need it).

The speaker actually accept it but she/he gives a requirement for the interlocutors to make them obey the interlocutor's request.

\section{Non-committal responses}

This category refers to a category of responses that the speaker does not give a spesific answer. The speaker deliberately left up in the air his/ her responses and allowed the interlocutor to make decisions (Aziz, 2000, p. 80). These are the following examples are taken from the respondents which answered non-committal responses situation.

Aruh punten tos ngarerepot (R12, S4).

(oh sorry, I've made a difficulties for you).

Hatur nuhun pa sateuacana, abdi ngaraos henteu enak panginten atos bantosanana. (R14, S8).

(Thanks before sir, I am shy for your help).

They give the answer but they do not tell it spesifically wheather they accept or refuse it. They think that the interlocutors might interpret their answer without the direct answer from the speaker.

\section{Comments without exemplification}

This strategy can be acceptance and also refusals because the responses clearly indicated that the respondents would either accept or refuse the request uttered by their interlocutor. These are the following examples are taken from the respondents which answered comments without exemplification situation.

Abdi narima. Da abdi butuh teras abdi oge dicarekan ku bapa pami nolak maksad sae mamang, pan lamun teu nurut ka kolot matak dosa (R13, S4).

(I accept because I need it, then my father will be angry to me if I refuse your kind purpose. It will be $\sin$ if I don't obey my father).

Abdi narima mang nu tos nambutkeun leptop $\mathrm{ka}$ abdi jadi abdi tiasa nyusun skripsi tur enggal enggal (R15, S4).

(I accept that you had borrowed your computer so I can do my thesis as soon as possible).

\section{CONCLUSION}

Based on findings above we can see that the refusal strategies consist of 12 strategies such as hesitation and lack of enthusiasm, offer an alternative, postponement, put the blame on a third party, general acceptance of an offer but giving no details, general acceptance with excuse, giving reason and explanation, conditional yes, questioning the justification of a request,threatening and comments without exemplification. While, the strategy of accepting consists of 6 strategies such as general yes or IFID, a rethorical response, expression of solidarity, acceptance with reservations, non-committal responses and comments without exemplification.

Most of the respondents which are Sundanese are polite because it can be seen from their respond when they are asking for accompanying their lecturer or when they refused to the person with high power, they choose the polite words. They always say punten, hapunten sateuacana or it can be called 'sorry'. The term sorry shows that they have a polite when talking with the higher power and distance. But they used different talking when they talk to their friend whih has same power. So they can place where they should be polite and to whom they talk.

\section{REFERENCES}

Aziz, E, A. (2000). Refusing in Indonesian: Strategies and politeness implications. Unpublished dissertation in Department of Linguistics. Australia: Monash University.

Jailifar, A. (2009). Request strategies: Cross-Sectional study of Iranian EFL learners and Australian native speakers. www.ccsenet.org/journal.html, 2(1). 
Indonesian EFL Journal, Vol. 4(2) July 2018

p-ISSN 2252-7427, e-ISSN 2541-3635

Kreidler, C, W. (1998). Introducing English Semantics. London and NewYork: Routledge Press.

Leech, G. (1983). Principles of pragmatics. New York: Longman Group Inc.

Maxwell, J, A. (1996). Qualitative research design: An interactive approach. California: Sage Publications, Inc.

Oatey, H, S. (2000). Culturally speaking: Culture, communication and politeness theory (2nd ed.). London: Continuum International Publishing Group.

Ogiermann, E. (2009). On apologizing in negative and positive politeness culture. Amsterdam: John Benjamin Publishing company.

\section{AISEE \\ The Association of Indonesian
Scho lars of English Education}

Reiter, R, M. (2000). Linguistic politeness in Britain and Uruguay: A contrastive study of requests and apologies. Amsterdam: John Benjamins Publishing Company.

Shelley, C. (1992). Speech acts and pragmatics in sentence generation. University of Waterloo: Canada.

Sugiyono. (2012). Metode penelitian pendidikan. Bandung: Alfabeta.

Thomas, J. (1995). Meaning in interaction: An introducing to pragmatics. New York: Longman Publishing. 